\title{
Religiosity and its Relationship with Smoking Cessation: A Systematic Review
}

\author{
Junainah A. ${ }^{a}$, Sharifah Munirah S.E. ${ }^{b}$, Mohd Said N. ${ }^{c}$, Hanida Hani M.M. ${ }^{a}$ \\ ${ }^{a}$ Department of Medical Surgical Nursing, Kulliyyah of Nursing, IIUM, Kuantan Campus, Pahang \\ ${ }^{b}$ Department of Special Care Nursing, Kulliyyah of Nursing, IIUM, Kuantan Campus, Pahang \\ ${ }^{C}$ Department of Critical Care Nursing, Kulliyyah of Nursing, IIUM, Kuantan Campus, Pahang
}

\begin{abstract}
Even though there were various interventions for cessation programs to date but smoking prevalence remains increasing from time to time. Since religiosity plays an important role in regulating one's health behaviour, hence the objective of the study is to systematically review the literature regarding the relationship between religiosity and smoking behaviour. Four electronic databases were used to identify the works of literature including Scopus, Science Direct, ProQuest, and PubMed. The search was limited to full-text articles and in English or Malay only. Articles on smoking prevention and other nicotine delivering devices such as vape or electronic cigarettes were excluded from the study. Initially, 10,154 articles were

Keywords

Religiosity, Islamic, Smoking Cessation

Corresponding Author

Dr. Junainah Azmi

Department of Medical Surgical Nursing, Kulliyyah of Nursing,

International Islamic University Malaysia,

25200 Kuantan, Pahang.

Tel No: +012-9661584

E-mail: junainahazmi@iium.edu.my

Received: 23 September 2020; Accepted: 22 May 2021

Doi: https://doi.org/10.31436/imjm.v20i4 retrieved and 12 met the inclusion criteria. Out of the 12 studies, five studies revealed a significant relationship between religious activities and cessation while the others showed inverse associations between religiosity and smoking. From the works of literature, we can conclude that religiosity played an important role in influencing smoking behaviour, making it an important vehicle to complement other existing tobacco control efforts. Limited studies were focusing on the Islamic religion despite the growing number of Muslim populations worldwide. Thus, further research on the integration of Islamic religion in smoking cessation programs is highly recommended especially in a Muslim country like Malaysia.
\end{abstract}

\section{INTRODUCTION}

Smoking is a major problem globally and has been linked to various kinds of chronic diseases such as oral and lung cancer, lung diseases, and heart diseases. ${ }^{1}$ Not only had it affected the smokers' health, but passive smokers also being badly affected by cigarette smoke as evidenced by almost 890,000 non-smokers who died being secondary smokers. ${ }^{2}$ Approximately 22.8\% $(4,991,458)$ of Malaysian were smokers and most of them started smoking as early as 15 years old. ${ }^{3}$

Previous smoking cessation programs mostly focused on whether pharmacotherapy or the behavioural counselling or a combination of both therapies, but only a few put religious-based intervention into consideration. ${ }^{4}$ Since religion is a very promising element in regulating a person's health behaviour, 5 it is important to develop and evaluate the effectiveness of religiousbased smoking cessation programs among smokers especially at the university level as this age group of students shown to have good responses with religious interventions. ${ }^{6,7}$

Withdrawal symptoms were commonly physical and psychological symptoms that may need some spiritual/ religious coping. According to Aldwin et al. (2014), religion as an element in spirituality helps regulate behaviour and health habits, while spirituality regulates emotions. ${ }^{5}$ Hence, religious-based interventions may be 
a very promising tool to increase smokers' spiritual ability to cope with the withdrawal effects with or without pharmacotherapy.

Religiosity includes religious coping; the use of religious belief which is believing that God has the ultimate power to control or change their heart and behaviour, and religious coping which allow them to cope with the emotional stress of their daily life by practicing religious practice such as praying, meditating, reading religious scriptures, attending religious services, performing religious rituals of relying on support from religious groups. ${ }^{8}$ Hence, the review aimed to investigate the current literatures regarding the relationship between religiosity and smoking behaviour.

\section{MATERIALS AND METHODS}

\section{Search strategies}

The literature search was guided by a search framework of Preferred Reporting Items for Systematic Review and Meta-Analyses (PRISMA). The detailed framework was summarized in Figure 2.1 below. Four electronic databases were searched using Boolean operators and truncation and the search strings are; ((religio* OR spiritual*) AND (cigarette* OR tobacco OR smoking)).

\section{Inclusion and exclusion criteria}

The search was limited to articles or review papers that were published from 2013 until 2020 to collect and provide the latest information regarding the topic. Published journals were hand searched for relevant literature using reference lists and citations made in the key publications. In summary, the inclusion and exclusion criteria of the literature search were as follow:

Inclusion criteria of the literature search:

1. Studies on religious activities in cigarette smoking cessation programs.

2. Limited to full-text articles.

3. Articles were published from 2013 to 2020.

Exclusion criteria of the literature search included:

1. Articles on smoking prevention.
2. Articles are written in other than English or Malay language.

3. Studies on other tobacco and nicotine delivering devices such as waterpipe tobacco, vape, or electronic cigarette.

\section{Assessment of methodological quality}

A quality assessment was completed for each article using; Strobe checklist by von Elm et al. (2008) for cohort and cross-sectional studies, while for mixedmethod, quasi-experimental, ${ }^{9}$ and randomised controlled trial (RCT), Joanna Briggs Institute critical appraisal tool by The Joanna Briggs Institute (2016) was used. ${ }^{10}$ Two researchers were involved in assessing methodological quality to reduce bias.

\section{RESULTS}

\section{Studies selection}

Of 10,154 articles that were found, 12 studies were assessed for methodological quality, and all were included in the review. The studies were chosen based on the score using the checklist of the appraisal tool and the score of 17 and above over 21 points are accepted, as agreed by all of the team members. The 12 studies were further undergone the data extraction and synthesis process. The 12 studies were further undergone the data extraction and synthesis process. The studies included in the review were listed in Table 3.1 and the appraisal of the studies was summarized in Table 3.2 .

\section{Data extraction and analysis}

Literatures found were analysed and the characteristics of each study were independently extracted by the researcher using an extraction table. The extracted data were compared and their discrepancies were discussed between the research committee members where necessary. The data were extracted and grouped according to the study setting, research aim, sample size, study design, outcome measures, study findings, limitations, and recommendations from the study. These data were presented in Table 2.2. 


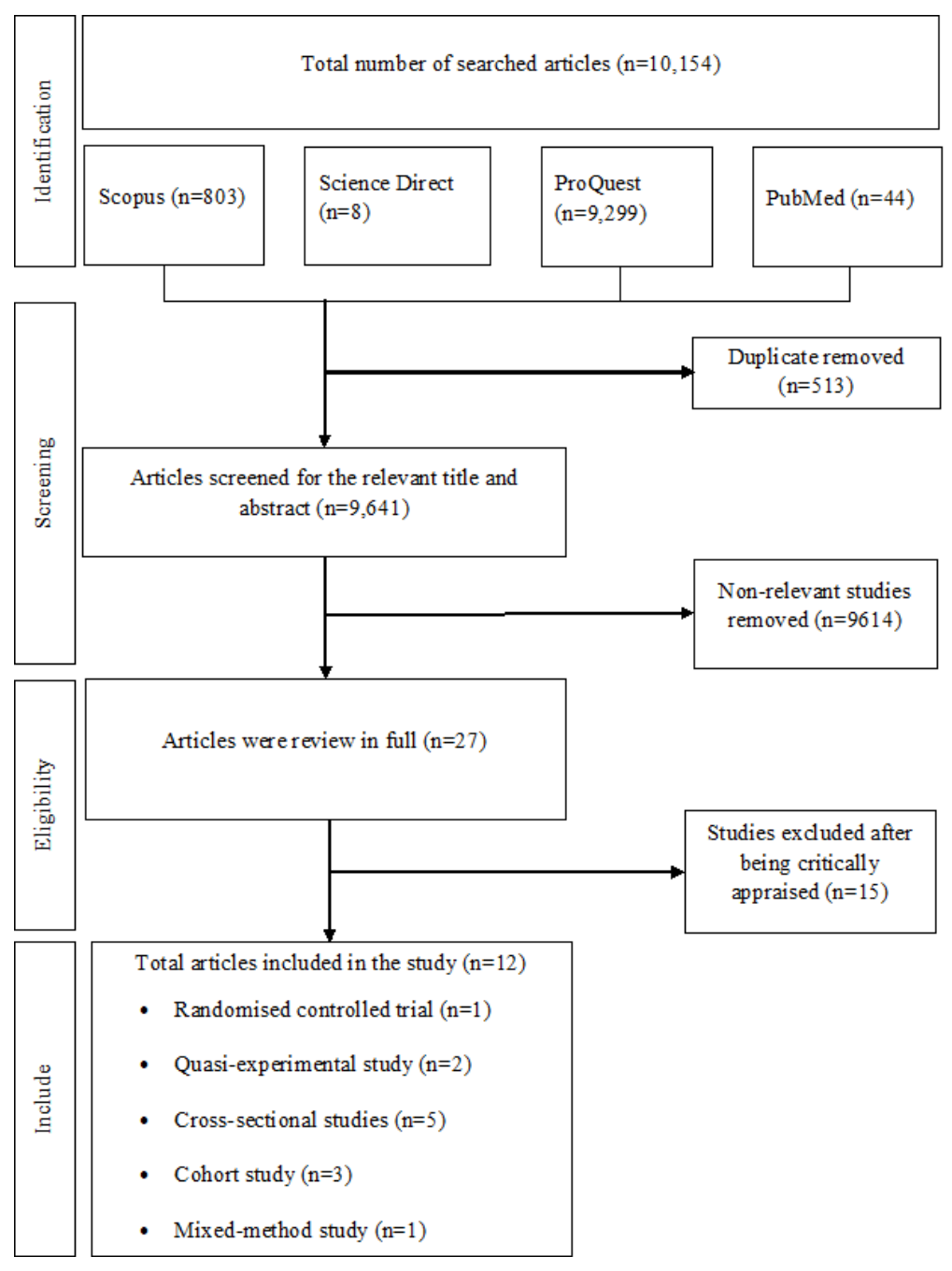

Figure 1: PRISMA flow diagram of the search strategy for the literature review.

\section{Synthesis of Study Findings}

Due to heterogeneity of the results such as different methodological approaches, different findings, and a limited number of studies for religious-based cessation programs, it was not possible to conduct a meta-analysis of these outcomes. Therefore, the results were presented in narrative form, including tables to clarify these.

\section{Studies characteristics}

Out of the twelve (12) studies, three (3) studies were conducted in the United States (US), ${ }^{12-14}$ one (1) study was done in Germany, ${ }^{15}$ while the rest of eight (8) studies were conducted in Asian countries; Saudi Arabia, China, Cambodia, Indonesia, Thailand, and Malaysia., $4,16-21$ Five (5) studies were cross-sectional studies, $7,8,12,16,19$ three (3) were cohort studies, ${ }^{13,14,20}$ two (2) quasi-experimental, ${ }^{15,21}$ one (1) mixed-method study, ${ }^{17}$ and another one (1) was an RCT. ${ }^{4}$

\section{Key descriptions of the studies}

A study by Bowie et al. (2016), examined the relationship between religious attendance and cigarette smoking in a sample of Black men in the US.12 They found that religious attendance was associated with lower smoking rates that present additional evidence that not only regular religious attendance may encourage smokers to reduce negative health behaviours; cigarette smoking but also it will encourage them to consider positive health practices; cessation.

Although the result showed a significant relationship between religious attendance and smoking behaviour; however, the study only measured religious attendance as the measurement of religiosity. Multiple dimension of religiosity is required to understand its impact on smoking behaviour comprehensively. 
Table 3.1: List of Studies Included in the Review

\begin{tabular}{lll}
\hline Studies (N=12) & $\begin{array}{l}\text { Context of } \\
\text { Studies }\end{array}$ \\
\hline Bowie et. al. & $(2016)$ & United States \\
Kerrin & $(2012)$ & United States \\
Brown et. al. & $(2014)$ & United States \\
Nunziata \& Toffolutti & $(2019)$ & Germany \\
Almutairi & $(2015)$ & Saudi Arabia \\
Wang, Koenig, \& Shohaib & $(2015)$ & China \\
Yel et. al. & $(2013)$ & Cambodia \\
Widyaningrum \& Yu & $(2018)$ & Indonesia \\
Elkalmi et. al. & $(2015)$ & Malaysia \\
Suriani et. al. & $(2016)$ & Malaysia \\
Yong, Savvas, Borland, \& Omar & $(2013)$ & $\begin{array}{l}\text { Malaysia \& } \\
\text { Thailand } \\
\text { Aida Maziha, Imran, Azlina, \& }\end{array}$ \\
\hline
\end{tabular}

In addition, a longitudinal study was conducted to further explore the relationship between spirituality and smoking cessation. ${ }^{13}$ The study was conducted among 178 cigarette smokers at the University of Pennsylvania and Northwestern University, US. The study involved assessing the smokers' spiritual well-being status at baseline and giving $21 \mathrm{mg}$ transdermal nicotine patch along with smoking cessation counselling over 8 weeks. The study utilized the Spiritual Well Being scale by Hawk et. al., (1995) to determine if spiritual well-being was a predictor of abstinence at the 8-week mark. Although this main relationship was not significant, other findings grant for a more in-depth study concerning this area. For instant, the study found a significant relationship between religious well-being and compliance with patch use which shows that there was a positive effect of religiosity on health behaviour.

Another study was done in the US to examine the influence of religious attendance on smoking status over time among a diverse sample of middle-aged lifetime smokers who reside in an urban setting. ${ }^{14}$ The authors hypothesised that higher frequencies of religious attendance would be associated with smoking cessation in the particular population. They found a significant inverse relationship between religious attendance and smoking. Religious attendance of more than once per week was associated with a $53 \%$ increase in smoking cessation among the study sample population (CR: 1.53; 95\% CI 1.10,2.13).
In East Germany, a quasi-experimental study was done by Nunziata \& Toffolutti (2019), to determine whether religious affiliation may prevent smoking among believers. ${ }^{15}$ The result of the study shows that atheism is positively and significantly correlated with smoking. The probability that an individual will be a smoker increases by around 7\% when an individual is an atheist $\left(\mathrm{R}^{2}=0.0644\right)$. The authors conclude that religious ethics have restraining effects on unhealthy behaviour, and suggested that religious affiliation is a relevant element that policymakers should consider when targeting antismoking intervention.

In Cambodia, a nation that is predominantly Buddhist, a cross-sectional study was done by Yel, Bui, Job, Knutsen, \& Singh, (2013) showed that religious-based intervention can be an effective part of the anti-tobacco campaign as the anti-tobacco sentiments are highly prominent in the Buddhist belief system in Cambodian adults. ${ }^{18}$ This can be evidence for religions' effects on one's health behaviour whether to practice positive or negative health behaviour. For an instant, religious belief may shape one's decisions whether to smoke or not.

On top of that, there was a study in Indonesia that explored the association between tobacco use and religious involvement among the Muslim population in the country. ${ }^{19}$ This cross-sectional study findings indicate that Muslims who perform the obligatory praying as regulated in Islam (5 times a day) are less likely to use tobacco, and those who smoke are more likely to stop or smoke less. The study recommended that reducing tobacco prevalence in predominantly Muslim countries may include incorporating religious interpretations about smoking.

In Malaysia, there was a study done to examine the perception and opinions of Malaysian Muslim students toward smoking. ${ }^{7}$ They conducted a cross-sectional study among smokers and non-smokers students in one of the Islamic universities in Malaysia; the International Islamic University Malaysia. The result shows that the majority of the smokers were aware of the fatwa for forbidding smoking practice in Islam and there was a significant number $(94 \%)$ of non-smokers believed that Islam prohibits smoking because of its potential harm. Some of the participants agreed that addiction is the 
main barrier to smoking cessation. The result showed that religious belief highly affects the smoking behaviour among students which could be a strong point to be considered.

Another literature that studies on religious beliefs on smoking behaviour was conducted on the Muslim Malaysian and Buddhist Thai smokers. ${ }^{20}$ The majority of both religious groups perceived that their religion discouraged smoking (78\% Muslim Malaysians and 86\% Buddhist Thais) but considerably more Buddhist Thais than Muslim Malaysians perceived that their society disapproved of smoking ( $80 \%$ versus $25 \%$ ). This result suggested that in Malaysia, where tobacco control has been relatively weak, until more recently, religion plays a greater role in smoking behaviour as compared to the societal norms.

Apart from that, there was a study done to examine the effects of a faith-based smoking cessation intervention during Ramadhan (the fasting month in Islam) among Malay male smokers in Malaysia. ${ }^{21}$ The intervention used in the study was developed based on the constructs within the Theory of Planned Behaviour which combines social influences and personal factors as predictors and also have been made tailored to Muslim smokers' culture. The components that contribute to behavioural change include intention, attitude, subjective norms, and perceived behaviour control. The study makes use of the uniqueness of the Ramadhan environment where there is a temporary norm of no smoking in public during the day for the whole month. The study found that the number of respondents who quit smoking during Ramadhan was higher in the intervention group compared to the control group that might be due to the positive effect of the faith-based intervention apart from changes of the other components mentioned above. This result suggests the positive value of religion in smoking cessation programs among Muslim Malaysian smokers.

The latest local literature that studied the effect of religious activities on smoking behaviour was done by Aida Maziha et al., (2018). ${ }^{4}$ The randomised control trial was done on fifty smokers attending an outpatient clinic in a tertiary teaching hospital in Malaysia. All of the participants were taught the techniques to quit smoking, including setting a quit date, removing all of the cigarettes and ashtrays, telling their family members about their attempt to quit and ways to cope with smoking urges. The intervention group was taught to recite four chapters of the Quran and concentrating on the meaning of the verse while the control group was taught the 12'M' method. The study discovered that the Al-Quran recitation led to a significant difference in reducing the cigarettes smoked compared to counselling with the 12'M' method. Although the primary outcome; which was the smoking intensity, was selfreported by the participants, it was a piece of good evidence to improve cessation efforts by reducing cravings and relapse by using the religious method.

\section{DISCUSSION}

\section{Role of religiosity/spirituality in influencing smoking behavior}

Men who regularly attending religious services had a lower odds of being a current smoker as compared to men who reported never attending religious services. ${ }^{12}$ Regular religious attendance also was inversely associated with smoking status. ${ }^{14,17}$ Literature also shows a significant relationship between religiosity and reduction in cigarette smoked. ${ }^{4}$ Furthermore, atheists are found to be $13-19 \%$ more likely to smoke than religious individuals. ${ }^{15}$ These results of an inverse relationship between religiosity and smoking behaviour provide a strong justification for religious integration in the smoking cessation program.

\section{Limited studies}

From this review, it was noted that spirituality and religiosity were inversely related to tobacco use and significantly related to the successful cessation rate among smokers.4,12,19 However, studies examining the relationship between spiritual/religiosity and tobacco use in Muslim-majority countries especially in Malaysia were still very limited. The studies on the role of religion on smoking behaviour were limited mostly to the university students in Malaysia, ${ }^{7}$ Thai-Buddhist smokers in Malaysia and Thailand, ${ }^{20}$ smoking cessation during Ramadhan among Malay smokers in Malaysia, ${ }^{21}$ and smoking intensity among Muslim men who are trying to quit smoking. ${ }^{4}$ 
Table 3.2: Assessment of the literature using appropriate appraisal tools

\begin{tabular}{|c|c|c|c|c|c|c|c|c|c|c|c|c|}
\hline Checklist items & $\begin{array}{l}\text { Bowie } \\
\text { et. al. } \\
\text { (2016) }\end{array}$ & $\begin{array}{l}\text { Kerrin } \\
(2012)\end{array}$ & $\begin{array}{l}\text { Brown } \\
\text { et. al. } \\
\text { (2014) }\end{array}$ & $\begin{array}{l}\text { Nunziata } \\
\& \\
\text { Toffolutti } \\
(2019)\end{array}$ & $\begin{array}{l}\text { Almutairi } \\
(2015)\end{array}$ & $\begin{array}{l}\text { Wang, } \\
\text { Koenig, \& } \\
\text { Shohaib } \\
(2015)\end{array}$ & $\begin{array}{l}\text { Yel, Bui, } \\
\text { Job, } \\
\text { Knutsen, } \\
\text { \& Singh } \\
(2013)\end{array}$ & $\begin{array}{l}\text { Widyaningrum } \\
\text { \& Yu (2018) }\end{array}$ & $\begin{array}{l}\text { Elkalmi, } \\
\text { Alkoudman } \\
\text { i, Elsayed, } \\
\text { Ahmad, \& } \\
\text { Khan } \\
(2015)\end{array}$ & $\begin{array}{l}\text { Yong, } \\
\text { Savvas, } \\
\text { Borland, } \\
\text { \& Omar } \\
(2013)\end{array}$ & $\begin{array}{l}\text { Ismail } \\
\text { et al. } \\
\text { (2016) }\end{array}$ & $\begin{array}{l}\text { Aida } \\
\text { Maziha, } \\
\text { Imran, } \\
\text { Azlina, } \\
\text { \& } \\
\text { Harmy } \\
(2018) \\
\end{array}$ \\
\hline $\begin{array}{l}\text { Title \& } \\
\text { Abstract }\end{array}$ & Y & $\mathrm{Y}$ & Y & Y & $\mathrm{Y}$ & $\mathrm{Y}$ & Y & $\mathrm{Y}$ & $\mathrm{Y}$ & $\mathrm{Y}$ & Y & $\mathrm{Y}$ \\
\hline $\begin{array}{l}\text { Introduction } \\
\text { 1. Background/ } \\
\text { Rationale }\end{array}$ & Y & Y & Y & Y & $\mathrm{Y}$ & Y & $\mathrm{Y}$ & $\mathrm{Y}$ & $\mathrm{Y}$ & $\mathrm{Y}$ & Y & $\mathrm{Y}$ \\
\hline 2. Objectives & Y & Y & Y & Y & $\mathrm{Y}$ & Y & $\mathrm{Y}$ & $\mathrm{Y}$ & $\mathrm{Y}$ & $\mathrm{Y}$ & Y & $\mathrm{Y}$ \\
\hline Method & & & & & & & & & & & & \\
\hline 3. Study design & Y & Y & Y & Y & $\mathrm{Y}$ & Y & $\mathrm{Y}$ & $\mathrm{Y}$ & $\mathrm{Y}$ & $\mathrm{Y}$ & $\mathrm{Y}$ & Y \\
\hline 4. Setting & Y & Y & Y & $\mathrm{Y}$ & Y & Y & Y & $\mathrm{Y}$ & $\mathrm{Y}$ & $\mathrm{Y}$ & $\mathrm{Y}$ & $\mathrm{Y}$ \\
\hline 5. Participants & Y & $\mathrm{Y}$ & $\mathrm{Y}$ & Y & $\mathrm{Y}$ & Y & $\mathrm{Y}$ & Y & $\mathrm{Y}$ & $\mathrm{Y}$ & $\mathrm{Y}$ & $\mathrm{Y}$ \\
\hline 6. Variables & $\mathrm{Y}$ & Y & Y & $\mathrm{Y}$ & Y & Y & $\mathrm{Y}$ & $\mathrm{Y}$ & $\mathrm{Y}$ & $\mathrm{Y}$ & Y & $\mathrm{Y}$ \\
\hline $\begin{array}{l}\text { 7. Data } \\
\text { sources/ } \\
\text { measurements }\end{array}$ & $\mathrm{Y}$ & Y & Y & Y & $\mathrm{Y}$ & $\mathrm{Y}$ & $\mathrm{NC}$ & $\mathrm{Y}$ & $\mathrm{Y}$ & $\mathrm{NC}$ & $\mathrm{Y}$ & Y \\
\hline 8. Bias & $\mathrm{N}$ & $\mathrm{N}$ & $\mathrm{N}$ & $\mathrm{N}$ & $\mathrm{N}$ & $\mathrm{N}$ & $\mathrm{N}$ & $\mathrm{N}$ & $\mathrm{N}$ & $\mathrm{N}$ & $\mathrm{Y}$ & $\mathrm{Y}$ \\
\hline 9. Study size & $\mathrm{Y}$ & Y & Y & Y & $\mathrm{Y}$ & $\mathrm{Y}$ & $\mathrm{Y}$ & $\mathrm{Y}$ & $\mathrm{Y}$ & $\mathrm{Y}$ & $\mathrm{Y}$ & Y \\
\hline $\begin{array}{l}\text { 10. Quantitative } \\
\text { variables }\end{array}$ & $\mathrm{Y}$ & Y & Y & $\mathrm{Y}$ & Y & $\mathrm{Y}$ & Y & $\mathrm{Y}$ & $\mathrm{Y}$ & $\mathrm{Y}$ & Y & $\mathrm{Y}$ \\
\hline $\begin{array}{l}\text { 11. Statistical } \\
\text { Method }\end{array}$ & $\mathrm{Y}$ & $\mathrm{Y}$ & Y & Y & $\mathrm{Y}$ & $\mathrm{Y}$ & Y & $\mathrm{Y}$ & $\mathrm{Y}$ & $\mathrm{Y}$ & Y & Y \\
\hline $\begin{array}{l}\text { Results } \\
\text { 12. Participants }\end{array}$ & Y & Y & Y & Y & Y & Y & Y & Y & Y & Y & Y & Y \\
\hline $\begin{array}{l}\text { 13. Descriptive } \\
\text { data }\end{array}$ & Y & Y & $\mathrm{Y}$ & $\mathrm{Y}$ & $\mathrm{Y}$ & $\mathrm{Y}$ & $\mathrm{Y}$ & $\mathrm{Y}$ & $\mathrm{Y}$ & Y & $\mathrm{Y}$ & Y \\
\hline $\begin{array}{l}\text { 14. Outcome } \\
\text { data }\end{array}$ & $\mathrm{Y}$ & Y & Y & Y & $\mathrm{Y}$ & Y & $\mathrm{Y}$ & $\mathrm{Y}$ & $\mathrm{Y}$ & $\mathrm{Y}$ & Y & Y \\
\hline 15. Main results & Y & Y & Y & Y & Y & $\mathrm{Y}$ & Y & $\mathrm{Y}$ & $\mathrm{Y}$ & $\mathrm{Y}$ & $\mathrm{Y}$ & $\mathrm{Y}$ \\
\hline $\begin{array}{l}\text { 16. Other } \\
\text { analyses }\end{array}$ & $\mathrm{NA}$ & Y & $\mathrm{NA}$ & $\mathrm{Y}$ & $\mathrm{NA}$ & Y & $\mathrm{NA}$ & $\mathrm{NA}$ & NA & $\mathrm{NA}$ & Y & $\mathrm{NA}$ \\
\hline $\begin{array}{l}\text { Discussion } \\
\text { 17. Key results }\end{array}$ & Y & Y & Y & Y & Y & Y & Y & Y & Y & Y & Y & Y \\
\hline 18. Limitations & Y & $\mathrm{N}$ & Y & $\mathrm{N}$ & $\mathrm{Y}$ & $\mathrm{Y}$ & $\mathrm{N}$ & Y & $\mathrm{Y}$ & $\mathrm{Y}$ & Y & $\mathrm{Y}$ \\
\hline $\begin{array}{l}19 . \\
\text { Interpretation }\end{array}$ & $\mathrm{Y}$ & $\mathrm{Y}$ & $\mathrm{Y}$ & $\mathrm{Y}$ & $\mathrm{Y}$ & $\mathrm{Y}$ & $\mathrm{Y}$ & $\mathrm{Y}$ & Y & Y & $\mathrm{Y}$ & $\mathrm{Y}$ \\
\hline $\begin{array}{l}20 . \\
\text { Generalizability }\end{array}$ & $\mathrm{Y}$ & $\mathrm{N}$ & $\mathrm{N}$ & $\mathrm{N}$ & $\mathrm{Y}$ & $\mathrm{Y}$ & $\mathrm{N}$ & $\mathrm{Y}$ & $\mathrm{Y}$ & $\mathrm{NC}$ & Y & $\mathrm{Y}$ \\
\hline $\begin{array}{l}\text { 21. Other } \\
\text { information } \\
\text { Funding }\end{array}$ & Y & $\mathrm{N}$ & Y & $\mathrm{Y}$ & $\mathrm{N}$ & $\mathrm{Y}$ & $\mathrm{Y}$ & $\mathrm{N}$ & $\mathrm{N}$ & $\mathrm{Y}$ & $\mathrm{N}$ & $\mathrm{N}$ \\
\hline
\end{tabular}

$\mathrm{Y}=$ Clear, $\mathrm{N}=$ Not mention, $\mathrm{NC}=$ Not clear, $\mathrm{NA}=$ Not applicable

*Appraised based on Strobe checklist for cohort and cross-sectional study and the Joanna Brigss Institute appraisal tool for quasi-experimental, mixed-method study, and RCT.

Most of the studies were cross-sectional and cohort studies and only two studies applied religious-based interventional in their smoking cessation program; one RCT, ${ }^{4}$ and the other one is a quasi-experimental study. ${ }^{21}$ This means that there was a limited number of religion-based smoking cessation programs that warrant the development of such programs especially in a Muslim country like Malaysia.

\section{Quality of the studies}

Some of the studies only relied on a self-reported measure of smoking status which is not accurately verifying the smoker's smoking status. ${ }^{12,19,20}$ It is very much proper to use biochemical testing such as amylase or urine cotinine level test to verify the smoking status of the smokers to produce reliable and congruent study results. Even so, since these types of biochemical tests are very budget-consuming, it is enough to verify the smoker's smoking status with the use of breath carbon monoxide (CO) level which is cheaper but also may produce a reliable result.

Apart from that, most studies only focusing on only one aspect of religiosity as a measure or intervention in the study; religious attendance, ${ }^{12}$ and another study only 
Table 2.2: Results of the literature search and the descriptions of the studies

\begin{tabular}{|c|c|c|c|c|c|c|}
\hline $\begin{array}{l}\text { Author \& } \\
\text { study } \\
\text { setting } \\
\end{array}$ & Research aim & $\begin{array}{l}\text { Sample } \\
\text { size }\end{array}$ & Study design & Outcome measures & Findings & $\begin{array}{l}\text { Limitation and } \\
\text { recommendation }\end{array}$ \\
\hline $\begin{array}{l}\text { 1. Bowie et. } \\
\text { al., } 2016 \\
\text { (US) }\end{array}$ & $\begin{array}{l}\text { To examine the } \\
\text { relationship } \\
\text { between religious } \\
\text { attendance and } \\
\text { cigarette smoking }\end{array}$ & $\begin{array}{l}1833 \text { US } \\
\text { Black men } \\
(1271 \\
\text { African \& } \\
562 \text { Black } \\
\text { Caribbean } \\
\text { men) }\end{array}$ & $\begin{array}{l}\text { Cross-sectional } \\
\text { study }\end{array}$ & $\begin{array}{l}\text { Smoking status (self- } \\
\text { reported), religious } \\
\text { attendance } \\
\text { Instruments: } \\
\text { Self-reported } \\
\text { smoking status and } \\
\text { religious attendance } \\
\text { scale. }\end{array}$ & $\begin{array}{l}\text { Religious attendance was } \\
\text { associated with lower rates of } \\
\text { cigarette smoking (odds ratio } \\
(\mathrm{OR})=0.21,95 \% \text { confidence } \\
\text { interval }(\mathrm{CI})= \\
0.07,0.62) \text { compared to men } \\
\text { who reported never attended } \\
\text { religious services. This shows } \\
\text { that regular religious } \\
\text { attendance might serve as a } \\
\text { protective factor against } \\
\text { cigarette smoking among the } \\
\text { study sample. }\end{array}$ & $\begin{array}{l}\text { Multiple dimensions of } \\
\text { religion are needed for a } \\
\text { more comprehensive } \\
\text { understanding of its } \\
\text { impact on health and } \\
\text { health behaviours, } \\
\text { including cigarette } \\
\text { smoking. }\end{array}$ \\
\hline $\begin{array}{l}\text { 2. Kerrin, } \\
2012 \text { (US) }\end{array}$ & $\begin{array}{l}\text { To assess the } \\
\text { relationship } \\
\text { between levels of } \\
\text { spiritual well-being } \\
\text { and abstinence } \\
\text { after an 8-week } \\
\text { nicotine patch } \\
\text { smoking cessation } \\
\text { treatment program }\end{array}$ & $\begin{array}{l}178 \\
\text { cigarette } \\
\text { smokers }\end{array}$ & $\begin{array}{l}\text { Longitudinal } \\
\text { study. Subjects } \\
\text { received the } \\
21 \mathrm{mg} \\
\text { transdermal } \\
\text { nicotine patch } \\
\text { for } 8 \text { weeks, } \\
\text { along with } \\
\text { smoking } \\
\text { cessation } \\
\text { counselling } \\
\text { (Cohort study) }\end{array}$ & $\begin{array}{l}\text { The primary } \\
\text { outcome variable } \\
\text { was 7-day point } \\
\text { prevalence } \\
\text { abstinence at Week } \\
8 \text {, } \\
\text { biochemically- } \\
\text { confirmed with CO } \\
\text { Instruments: } \\
\text { Questionnaire, } \\
\text { Spiritual well-being } \\
\text { scale, Smokerlyzer. }\end{array}$ & $\begin{array}{l}\text { No significant findings for } \\
\text { the relationship between the } \\
\text { spiritual well-being scale and } \\
\text { quitting smoking. } \\
\text { Relationships were found } \\
\text { between religious well-being } \\
\text { and compliance with patch } \\
\text { usage. Conclusion: smokers, } \\
\text { especially heavy smokers, } \\
\text { may be receptive to using } \\
\text { spiritual/religious resources } \\
\text { in a quit attempt. }\end{array}$ & $\begin{array}{l}\text { Future studies should look } \\
\text { at the relationship } \\
\text { between spirituality/ } \\
\text { religiosity and quitting } \\
\text { based on the number of } \\
\text { cigarettes smoked per day. } \\
\text { Spirituality and religiosity } \\
\text { in tobacco dependence } \\
\text { treatment warrant } \\
\text { additional investigation } \\
\text { and program } \\
\text { development. }\end{array}$ \\
\hline $\begin{array}{l}\text { 3. Brown, } \\
\text { et. al., } 2014 \\
\text { (US) }\end{array}$ & $\begin{array}{l}\text { To examine the } \\
\text { influence of } \\
\text { religious attendance } \\
\text { on smoking status } \\
\text { over time among a } \\
\text { diverse sample of } \\
\text { middle-aged } \\
\text { lifetime smokers } \\
\text { who reside in an } \\
\text { urban setting. }\end{array}$ & $\begin{array}{l}666 \\
\text { cigarette } \\
\text { smokers }\end{array}$ & $\begin{array}{l}\text { Prospective } \\
\text { Cohort study }\end{array}$ & $\begin{array}{l}\text { Smoking status (self- } \\
\text { reported) and religious } \\
\text { attendance (the } \\
\text { primary exposure). }\end{array}$ & $\begin{array}{l}\text { Attending religious services } \\
\text { about once per week was } \\
\text { associated with a } 32 \% \text { increase } \\
\text { in smoking cessation (ARR } \\
1.32 ; 95 \% \text { CI } 1.00,1.75) \text {, } \\
\text { whereas attending more than } \\
\text { once per week was associated } \\
\text { with a } 40 \% \text { increase in smoking } \\
\text { cessation (ARR } 1.40 ; 95 \% \text { CI } \\
1.01,1.95) \text {. }\end{array}$ & $\begin{array}{l}\text { Since the smoking status } \\
\text { was obtained via self-report, } \\
\text { there was potential for recall } \\
\text { bias. Considering there are } \\
\text { potential benefits of } \\
\text { religious attendance on } \\
\text { reducing smoking, public } \\
\text { health practitioners should } \\
\text { consider working with the } \\
\text { faith-based institution to } \\
\text { develop community-based } \\
\text { smoking cessation } \\
\text { programs. }\end{array}$ \\
\hline $\begin{array}{l}\text { 4.Nunziata } \\
\& \\
\text { Toffolutti, } \\
2019 \\
\text { (Germany) }\end{array}$ & $\begin{array}{l}\text { To analyse the } \\
\text { implications of } \\
\text { religious affiliation } \\
\text { on unhealthy } \\
\text { behaviour by } \\
\text { focusing on the link } \\
\text { between } \\
\text { religiousness and } \\
\text { smoking. }\end{array}$ & $\begin{array}{l}3,731 \text { males } \\
\text { born in } \\
\text { Germany }\end{array}$ & $\begin{array}{l}\text { Quasi- } \\
\text { experimental }\end{array}$ & $\begin{array}{l}\text { Socio-demographics, } \\
\text { smoking habits, and } \\
\text { religiousness. }\end{array}$ & $\begin{array}{l}\text { The results showed that } \\
\text { atheism is positively and } \\
\text { significantly correlated with } \\
\text { smoking and religiousness } \\
\text { significantly affects smoking } \\
\text { behaviour. }\end{array}$ & $\begin{array}{l}\text { The smoking status was } \\
\text { assessed by a declaration of } \\
\text { smoking habit by the } \\
\text { sample (self-reported } \\
\text { smoking status). }\end{array}$ \\
\hline $\begin{array}{l}\text { 5. Almutairi, } \\
\text { 2015 (Saudi } \\
\text { Arabia) }\end{array}$ & $\begin{array}{l}\text { To describe the } \\
\text { relationships of } \\
\text { smoking behaviour } \\
\text { among male college } \\
\text { students in Saudi } \\
\text { Arabia to their } \\
\text { religious practice, } \\
\text { parents smoking } \\
\text { behaviours and } \\
\text { attitudes, peers' } \\
\text { smoking } \\
\text { behaviours and } \\
\text { attitudes, and } \\
\text { knowledge about } \\
\text { the dangers of } \\
\text { smoking. }\end{array}$ & $\begin{array}{l}715 \\
\text { undergradu } \\
\text { ate male } \\
\text { students }\end{array}$ & $\begin{array}{l}\text { Cross-sectional } \\
\text { study }\end{array}$ & $\begin{array}{l}\text { Demographic } \\
\text { characteristics, the } \\
\text { practice of Islam, } \\
\text { cigarette, and sheesha } \\
\text { smoking status, } \\
\text { parents' tobacco use } \\
\text { and attitudes, and } \\
\text { knowledge of the } \\
\text { dangers of tobacco use } \\
\text { ( } 49 \text { questions } \\
\text { questionnaire). }\end{array}$ & $\begin{array}{l}\text { Logistic regression analysis } \\
\text { suggested the four smoking } \\
\text { predictors; low Islamic practice, } \\
\text { low knowledge about the } \\
\text { dangers of smoking, peers who } \\
\text { smoke, and peers who } \\
\text { approved of their friends } \\
\text { smoking. }\end{array}$ & $\begin{array}{l}\text { The generalizability of the } \\
\text { results is limited to the male } \\
\text { student only. However, it } \\
\text { can be generalized to other } \\
\text { male college students. There } \\
\text { is a need to increase } \\
\text { research in each of the areas } \\
\text { explored in this research. }\end{array}$ \\
\hline $\begin{array}{l}\text { 6. Wang, } \\
\text { Koenig, \& } \\
\text { Shohaib, } \\
2015 \\
\text { (China) }\end{array}$ & $\begin{array}{l}\text { To examine the } \\
\text { correlation } \\
\text { between religious } \\
\text { involvements and } \\
\text { tobacco use, and } \\
\text { to explore the } \\
\text { connection } \\
\text { between religiosity } \\
\text { and tobacco use in } \\
\text { Muslims and non- } \\
\text { Muslims in } \\
\text { Western China. }\end{array}$ & $\begin{array}{l}2,770 \\
\text { adults }\end{array}$ & $\begin{array}{l}\text { Mixed method } \\
\text { study }\end{array}$ & $\begin{array}{l}\text { Socio-demographic } \\
\text { variables, self- } \\
\text { reported smoking } \\
\text { status, history of } \\
\text { smoking, religious } \\
\text { importance, } \\
\text { attendance, and } \\
\text { affiliation. Anxiety } \\
\text { and mood disorders } \\
\text { were assessed using } \\
\text { the World Health } \\
\text { Organization } \\
\text { Composite } \\
\text { International } \\
\text { Diagnostic Interview } \\
\text { (WHO-CIDI). }\end{array}$ & $\begin{array}{l}\text { Overall sample: Religious } \\
\text { attendance was inversely } \\
\text { associated with smoking } \\
(\mathrm{p}<0.001) \text {, as was the } \\
\text { importance of religion } \\
\text { ( } \mathrm{p}<0.05 \text { ). Smoking is also less } \\
\text { common in those categorised } \\
\text { as high on religious } \\
\text { involvement. } \\
\text { Muslim sample: Both } \\
\text { religious attendance and high } \\
\text { religiosity were inversely } \\
\text { associated with smoking } \\
\text { ( }<<0.001 \text { ). No association } \\
\text { was found in the non-Muslim } \\
\text { sample. }\end{array}$ & $\begin{array}{l}\text { Generalization was limited } \\
\text { to the single province of } \\
\text { China. Additionally, } \\
\text { potential recall bias due to } \\
\text { subjective self-reported } \\
\text { smoking status could } \\
\text { influence the accuracy of } \\
\text { the participants' smoking } \\
\text { rates. }\end{array}$ \\
\hline
\end{tabular}




\begin{tabular}{|c|c|c|c|c|c|c|}
\hline $\begin{array}{l}\text { 7. Yel, Bui, } \\
\text { Job, } \\
\text { Knutsen, \& } \\
\text { Singh, 2013 } \\
\text { (Cambodia) }\end{array}$ & $\begin{array}{l}\text { To examine } \\
\text { and measure } \\
\text { the prevalence } \\
\text { of Buddhist } \\
\text { beliefs about } \\
\text { addiction and } \\
\text { tobacco use. }\end{array}$ & $\begin{array}{l}13,988 \\
\text { Cambodi } \\
\text { an adults }\end{array}$ & Survey & $\begin{array}{l}\text { Interviewer-administered } \\
\text { survey (Buddhist Beliefs Used } \\
\text { survey) }\end{array}$ & $\begin{array}{l}\text { Findings indicate that faith- } \\
\text { based initiatives could be an } \\
\text { effective part of anti-tobacco } \\
\text { campaigns in Cambodia. }\end{array}$ & $\begin{array}{l}\text { The efficacy of measures } \\
\text { relating to religious belief on } \\
\text { smoking cessation needs } \\
\text { further examination. }\end{array}$ \\
\hline $\begin{array}{l}8 . \\
\text { Widyaningru } \\
\mathrm{m} \& \mathrm{Yu} \\
2018 \\
\text { (Indonesia) }\end{array}$ & $\begin{array}{l}\text { To examine } \\
\text { the association } \\
\text { between } \\
\text { tobacco use } \\
\text { and religious } \\
\text { involvement } \\
\text { among the } \\
\text { Muslim } \\
\text { population }\end{array}$ & $\begin{array}{l}28,285 \\
\text { Indonesia } \\
\mathrm{n} \\
\text { Muslims }\end{array}$ & Survey & $\begin{array}{l}\text { Self-reported smoking } \\
\text { cessation, } \\
\text { Religious involvement } \\
\text { Questionnaires. }\end{array}$ & $\begin{array}{l}\text { This cross-sectional study } \\
\text { findings indicate that Muslims } \\
\text { who perform the obligatory } \\
\text { praying as regulated in Islam ( } 5 \\
\text { times a day) are less likely to use } \\
\text { tobacco, and those who smoke } \\
\text { are more likely to stop or smoke } \\
\text { less }\end{array}$ & $\begin{array}{l}\text { Reducing tobacco prevalence } \\
\text { in predominantly Muslim } \\
\text { countries may include } \\
\text { religious interpretation about } \\
\text { smoking }\end{array}$ \\
\hline $\begin{array}{l}\text { 9. Elkalmi, } \\
\text { Alkoudmani, } \\
\text { Elsayed, } \\
\text { Ahmad, \& } \\
\text { Khan, 2015 } \\
\text { (Malaysia) }\end{array}$ & $\begin{array}{l}\text { to examine the } \\
\text { perception and } \\
\text { opinions of } \\
\text { Malaysian } \\
\text { Muslim } \\
\text { students } \\
\text { toward } \\
\text { smoking }\end{array}$ & $\begin{array}{l}323 \\
\text { university } \\
\text { students. }\end{array}$ & $\begin{array}{l}\text { Cross- } \\
\text { sectional } \\
\text { study }\end{array}$ & $\begin{array}{l}\text { Demographic, students' } \\
\text { perceptions of the religious } \\
\text { impact on smoking, the } \\
\text { general opinion of students } \\
\text { towards smoking practice, and } \\
\text { factors encouraging and } \\
\text { discouraging the practice of } \\
\text { smoking. } \\
\text { Instruments: } \\
\text { Self-administered } \\
\text { questionnaire (Developed by } \\
\text { the authors). }\end{array}$ & $\begin{array}{l}\text { Islamic faith plays an important } \\
\text { role in determining the smoking } \\
\text { practices among students. }\end{array}$ & $\begin{array}{l}\text { Further studies are required to } \\
\text { validate these results by } \\
\text { involving students from the } \\
\text { different geographical regions } \\
\text { of Malaysia. }\end{array}$ \\
\hline $\begin{array}{l}\text { 10. Suriani et } \\
\text { al., } 2016 \\
\text { (Malaysia) }\end{array}$ & $\begin{array}{l}\text { To study the } \\
\text { effects of a } \\
\text { faith-based } \\
\text { smoking } \\
\text { cessation } \\
\text { intervention } \\
\text { during } \\
\text { Ramadan } \\
\text { among Malay } \\
\text { male smokers } \\
\text { working in } \\
\text { public offices } \\
\end{array}$ & $\begin{array}{l}62 \text { Malay } \\
\text { male } \\
\text { smokers } \\
\text { per arm. }\end{array}$ & $\begin{array}{l}\text { Quasi- } \\
\text { experimenta } \\
\text { l study }\end{array}$ & $\begin{array}{l}\text { Instruments: } \\
\text { Fagerstrom Test for Nicotine } \\
\text { Dependence (FTND) score } \\
\text { questionnaire, Salimetrics } \\
\text { salivary cotinine test }\end{array}$ & $\begin{array}{l}\text { A significant change between the } \\
\text { groups was only noticed during } \\
\text { Ramadan. Indicate the positive } \\
\text { effect of using this culturally } \\
\text { competent intervention to } \\
\text { encourage smokers to start } \\
\text { smoking cessation during } \\
\text { Ramadan }\end{array}$ & $\begin{array}{l}\text { The intervention was } \\
\text { developed based on the } \\
\text { constructs in the Theory of } \\
\text { Planned Behaviour (TPB). } \\
\text { Additional components of the } \\
\text { intervention must be } \\
\text { developed to help smokers } \\
\text { who had stopped smoking } \\
\text { during Ramadan from } \\
\text { returning to their old habits }\end{array}$ \\
\hline $\begin{array}{l}\text { 12. Aida } \\
\text { Maziha Z, } \\
\text { Imran A, } \\
\text { Azlina I, } \\
\text { Harmy MY, } \\
2018 \\
\text { (Malaysia) }\end{array}$ & $\begin{array}{l}\text { To test the } \\
\text { effects of Al- } \\
\text { Quran } \\
\text { recitation and } \\
\text { 12'M' } \\
\text { counselling on } \\
\text { smoking } \\
\text { intensity } \\
\text { among Muslim } \\
\text { smokers. }\end{array}$ & $\begin{array}{l}50 \\
\text { smokers }\end{array}$ & $\begin{array}{l}\text { Randomized } \\
\text { Control } \\
\text { Trial }\end{array}$ & $\begin{array}{l}\text { Instruments: } \\
\text { The questionnaire which } \\
\text { contained three } \\
\text { parts: demographic } \\
\text { information, smoking } \\
\text { characteristics (including a } \\
\text { Fagerstrom score), } \\
\text { and a religiosity scale (Muslim } \\
\text { Religiosity-Personality } \\
\text { Inventory Scale), Malay } \\
\text { version of the Wisconsin } \\
\text { Smoking Withdrawal } \\
\text { Score (WSWS), CO level at } \\
\text { 4weeks post-intervention } \\
\text { (using CO smokerlyzer). }\end{array}$ & $\begin{array}{l}\text { There was a statistically } \\
\text { significant difference in the } \\
\text { number of cigarettes smoked } \\
\text { between the Al-Quran recitation } \\
\text { and the 12'M' group. There was } \\
\text { also a statistically significant } \\
\text { difference in the change in } \\
\text { cravings between the groups. } \\
\text { Finding suggests that the Al- } \\
\text { Quran recitation approach is a } \\
\text { potential method with which to } \\
\text { improve smoking cessation } \\
\text { efforts. }\end{array}$ & $\begin{array}{l}\text { A bigger and more generalized } \\
\text { sample is needed for future } \\
\text { studies. The study only } \\
\text { focuses on the Al-Quran } \\
\text { recitation aspect of religiosity. } \\
\text { Future studies should also } \\
\text { include other aspects of } \\
\text { religiosity such as religious } \\
\text { attendance and so on. }\end{array}$ \\
\hline
\end{tabular}

focused on the Al-Quran recitation. ${ }^{4}$ Multiple dimensions of religion need to be examined for a more comprehensive understanding of the impact of religion/spirituality on health and health behaviour, particularly in smoking behaviour. The lack of theories integration in most studies warrants a need to integrate theories related to religiosity/spirituality for better guidance and understanding of the religiosity/ spirituality concepts related to health behaviour change.

\section{CONCLUSION}

The works of the literature showed that the majority of studies put attention on the Christian religion and 
developed countries like the US. There is an obvious need to focus on the Islamic-based intervention for Muslim smokers especially in the developing Muslim country like Malaysia. The works of literature also showed that religiosity/spirituality is an important factor for smoking cessation. Thus, providing a new alternative intervention that may complement other existing tobacco control efforts.

Despite the focus on religiosity being an important catalyst to quit or maintaining one's smoking-free status, neither researchers in other countries nor in Malaysia have addressed on what are the detailed religious aspects that make smokers quit or non-smoker maintains smoking-free. Thus, the need to develop a program with detailed religious aspects based on the Quran and Sunnah, hadith, and also from the religious experts' opinions, so can be referred by future researchers.

While studies conducted in Malaysia did not properly address the multiple dimension in the Islamic religion, this grants the need for developing a new religiousbased cessation program that will integrate all of the Islamic religion aspects to suit the Malaysian context. Furthermore, study on the effect of religious-based intervention in smoking cessation program in Malaysia is still very lacking and need to be done to improve the smoking phenomena in the country.

\section{AUTHORS' CONTRIBUTIONS}

JA conducted the literature searches and extracted data with input from SM. All authors were responsible for data interpretation. JA drafted the manuscript and all other authors revised and approved the manuscript.

\section{CONFLICTS OF INTEREST}

There were no conflicts of interest.

\section{ACKNOWLEDGEMENT}

The authors are much grateful to Kulliyyah of Nursing Post Graduate Research Committee (KNPGRC) and IIUM Research Ethics Committee (IREC) authority for allowing the implementation of this study. We also would like to acknowledge the International Islamic University of Malaysia for grant RMCG20-061-0061.

\section{REFERENCES}

1. CDC. Your Guide to the 50th Anniversary Surgeon General's; Report on Smoking and Health. 2015;

2. WHO. WHO Report on the Global Tobacco Epidemic, 2017; Monitoring tobacco use and prevention policies. 2017.

3. Institute for Public Health (IPH). NATIONAL HEALTH AND MORBIDITY SURVEY 2015 REPORT ON SMOKING STATUS AMONG MALAYSIAN ADULTS. Kuala Lumpur; 2015.

4. Aida Maziha Z, Imran A, Azlina I, Harmy M. Randomized controlled trial on the effect of AlQuran recitation vs counseling on smoking intensity among Muslim men who are trying to quit smoking. 2018;13(2):19-25.

5. Aldwin CM, Park CL, Jeong Y-J, Nath R. Differing Pathways Between Religiousness, Spirituality, and Health : A Self-Regulation Perspective. 2014;6(1):9-21.

6. Nurul 'Izzati A, Nor Azlina A, Nor Iza A, Mainul H. Knowledge, Attitude and Practice towards Smoking among International Islamic University Malaysia Kuantan Communities. 2016;15(2).

7. Elkalmi RM, Alkoudmani RM, Elsayed TM, Ahmad A, Khan MU. Effect of Religious Beliefs on the Smoking Behaviour of University Students: Quantitative Findings From Malaysia. J Relig Health. 2016;55(6):1869-75.

8. Mishra SK, Togneri E, Tripathi B, Trikamji B. Spirituality and Religiosity and Its Role in Health and Diseases. J Relig Health. 2015;

9. von Elm E, Altman DG, Egger M S.J. P, Gøtzsche PC, Vandenbroucke JP, Initiative S. The Strengthening the Reporting of Observational Studies in Epidemiology (STROBE)statement: guidelines for reporting observational studies. J Clin Epidemiol [Internet]. 2008;61(4):344-9. Available from: http://www.strobe-statement.org/ index.php?id $=$ strobe-publications

10. The Joanna Briggs Institute. Checklist for QuasiExperimental Studies. Joanna Briggs Inst [Internet]. 2016;1-6. Available from: http:// joannabriggs.org/assets/docs/critical-appraisaltools/JBI_Quasi-

Experimental_Appraisal_Tool2017.pdf

11. Primack BA, Mah J, Shensa A, Rosen D, Yonas 
MA, Fine MJ. Journal of Ethnicity in Substance

Abuse Associations Between Race, Ethnicity, Religion, and Waterpipe Tobacco Smoking. 2014;

(October):58-71.

12. Bowie J V, Parker LJ, Beadle-holder M, Ezema A, Bruce MA, Jr RJT, et al. The Influence of Religious Attendance on Smoking Among Black Men The Influence of Religious Attendance on Smoking Among Black Men. 2016;6084(January).

13. Kerrin K. Exploring the Relationship Between Spiritual Well-Being and Smoking Cessation Treatment. 2012; Available from: http:// repository.upenn.edu/edissertations_sp2http:// repository.upenn.edu/edissertations_sp2/70

14. Brown QL, Linton SL, Harrell PT, Mancha BE, Alexandre PK, Chen K, et al. The Influence of Religious Attendance on Smoking. 2015;1-8.

15. Nunziata L, Toffolutti V. SSM - Population Health "Thou Shalt not Smoke ": Religion and smoking in a natural experiment of history. SSM Popul Heal. 2019;8(May):100412.

16. Almutairi KM. Predicting Relationship of Smoking Behavior Among Male Saudi Arabian College Students Related to Their Religious Practice. J Relig Health. 2016;55(2):469-79.

17. Wang Z, Koenig HG, Al Shohaib S. Religious involvement and tobacco use in mainland China: A preliminary study. BMC Public Health. 2015;15 (1):1-9.

18. Yel D, Bui A, Job JS, Knutsen S, Singh PN. Beliefs About Tobacco, Health, and Addiction Among Adults in Cambodia: Findings from a National Survey. J Relig Health. 2013;52(3):90414.

19. Widyaningrum N, Yu J. Tobacco Use Among the Adult Muslim Population in Indonesia: A Preliminary Study on Religion, Cultural, and Socioeconomic Factors. J Drug Issues. 2018;48 (4):676-88.

20. Yong H, Savvas S, Borland R, Omar M. Secular Versus Religious Norms Against Smoking: Which Is More Important as a Driver of Quitting Behaviour Among Muslim Malaysian and Buddhist Thai Smokers? 2013;252-8.

21. Ismail $\mathrm{S}, \mathrm{Abdul}$ Rahman $\mathrm{H}$, Abidin EZ, Isha ASN, Abu Bakar S, Zulkifley NA, et al. The effect of faith-based smoking cessation intervention during Ramadan among Malay smokers. Qatar Med J. 2016;2016(2):1-10. 